\title{
Front Matter: Volume 9877
}

, "Front Matter: Volume 9877," Proc. SPIE 9877, Land Surface and Cryosphere Remote Sensing III, 987701 (1 December 2016); doi: 10.1117/12.2244908

SPIE. Event: SPIE Asia-Pacific Remote Sensing, 2016, New Delhi, India 


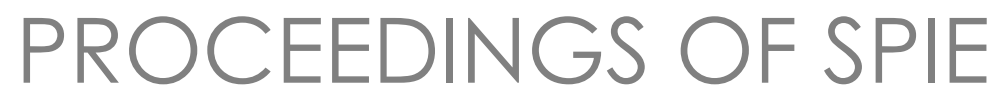

\title{
Land Surface and Cryosphere Remote Sensing III
}

\author{
Reza Khanbilvardi \\ Ashwagosh Ganju \\ A. S. Rajawat \\ Jing M. Chen \\ Editors
}

4-7 April 2016

New Delhi, India

Sponsored by

SPIE

Cosponsored by

ISRO_Indian Space Research Organization (India) • Ministry of Earth Sciences (India) • NASA—National Aeronautics and Space Administration (United States)

Cooperating Organizations

State Key Laboratory of Remote Sensing Science, Chinese Academy of Sciences (China) RADI-Institute of Remote Sensing and Digital Earth, Chinese Academy of Sciences (China) JAXA-Japan Aerospace Exploration Agency (Japan)

NICT-National Institute of Information and Communications Technology (Japan)

Local Host

ISRS—Indian Society of Remote Sensing (India)

Published by

SPIE

Volume 9877

Proceedings of SPIE 0277-786X, V. 9877

SPIE is an international society advancing an interdisciplinary approach to the science and application of light.

Land Surface and Cryosphere Remote Sensing III, edited by Reza Khanbilvardi, Ashwagosh Ganju,

A. S. Rajawat, Jing M. Chen, Proc. of SPIE Vol. 9877, 987701 · ( 2016 SPIE

CCC code: $0277-786 X / 16 / \$ 18 \cdot$ doi: $10.1117 / 12.2244908$ 
The papers in this volume were part of the technical conference cited on the cover and title page. Papers were selected and subject to review by the editors and conference program committee. Some conference presentations may not be available for publication. Additional papers and presentation recordings may be available online in the SPIE Digital Library at SPIEDigitallibrary.org.

The papers reflect the work and thoughts of the authors and are published herein as submitted. The publisher is not responsible for the validity of the information or for any outcomes resulting from reliance thereon.

Please use the following format to cite material from these proceedings:

Author(s), "Title of Paper," in Land Surface and Cryosphere Remote Sensing III, edited by Reza Khanbilvardi, Ashwagosh Ganju, A. S. Rajawat, Jing M. Chen, Proceedings of SPIE Vol. 9877 (SPIE, Bellingham, WA, 2016) Six-digit Article CID Number.

ISSN: 0277-786X

ISSN: 1996-756X (electronic)

ISBN: 9781510601185

Published by

SPIE

P.O. Box 10, Bellingham, Washington 98227-0010 USA

Telephone +1 3606763290 (Pacific Time) · Fax +1 3606471445

SPIE.org

Copyright (c) 2016, Society of Photo-Optical Instrumentation Engineers.

Copying of material in this book for internal or personal use, or for the internal or personal use of specific clients, beyond the fair use provisions granted by the U.S. Copyright Law is authorized by SPIE subject to payment of copying fees. The Transactional Reporting Service base fee for this volume is $\$ 18.00$ per article (or portion thereof), which should be paid directly to the Copyright Clearance Center (CCC), 222 Rosewood Drive, Danvers, MA 01923. Payment may also be made electronically through CCC Online at copyright.com. Other copying for republication, resale, advertising or promotion, or any form of systematic or multiple reproduction of any material in this book is prohibited except with permission in writing from the publisher. The CCC fee code is 0277-786X/16/\$18.00.

Printed in the United States of America.

Publication of record for individual papers is online in the SPIE Digital Library.

\section{SPIE. DIGITAL}

Paper Numbering: Proceedings of SPIE follow an e-First publication model. A unique citation identifier (CID) number is assigned to each article at the time of publication. Utilization of CIDs allows articles to be fully citable as soon as they are published online, and connects the same identifier to all online and print versions of the publication. SPIE uses a six-digit CID article numbering system structured as follows:

- The first four digits correspond to the SPIE volume number.

- The last two digits indicate publication order within the volume using a Base 36 numbering system employing both numerals and letters. These two-number sets start with 00, 01, 02, 03, 04, $05,06,07,08,09,0 A, 0 B \ldots$ OZ, followed by 10-1Z, 20-2Z, etc. The CID Number appears on each page of the manuscript. 


\title{
Contents
}

\author{
vii Authors \\ ix Symposium Committees \\ xi Conference Committee
}

SAR IMAGING FOR NISAR SCIENCE I: FOREST STRUCTURE AND VEGETATION

987705 Deorientation of PoISAR coherency matrix for volume scattering retrieval [9877-6]

987707 Performance of PoISAR backscatter and PollnSAR coherence for scattering characterization of forest vegetation using TerraSAR-X data [9877-8]

987708 Polarimetric SAR interferometry-based decomposition modelling for reliable scattering retrieval [9877-9]

987709 PollnSAR tomography for vertical profile retrieval of forest vegetation using spaceborne SAR data [9877-10]

\section{LAND DEGRADATION AND DESERTIFICATION}

9877 OK Terrestrial rock glaciers: a potential analog for Martian lobate flow features (LFF) [9877-24]

\section{AGRICULTURE AND CROP PRODUCTION}

$9877 \mathrm{ON}$ On the detection and monitoring of reduced water content in plants using spectral responses in the visible domain [9877-28]

9877 OP Delineating crop management zones in small fields using multi-temporal Landsat data [9877-30]

REMOTE SENSING OF SOIL MOISTURE I

9877 OU Analysis of groundwater anomalies using GRACE over various districts of Jharkhand [9877-37]

REMOTE SENSING OF SOIL MOISTURE II

9877 OV Monitoring of soil wetness variation using satellite microwave observations from the direct broadcast receiving system at IMD [9877-36] 
9877 OX Model-based surface soil moisture (SSM) retrieval algorithm using multi-temporal RISAT-1 C-band SAR data [9877-39]

9877 OY A synergistic approach for soil moisture estimation using modified Dubois model with dualpolarized SAR and optical satellite data [9877-40]

\section{APPLICATION OF SATELLITES ON LAND PROCESSES}

$98770 Z$ Emergency observation and its analysis using ALOS-2 PALSAR-2 in 2015 [9877-41]

987711 Relationship between surface temperature and SAVI using Landsat data in a coal mining area in India [9877-115]

\section{CRYOSPHERE REMOTE SENSING}

987712 NOAA NESDIS global multisensor automated satellite-based snow mapping system and products [9877-44]

987715 Glacier retreat monitoring from SAR coherence images: application to Gangotri glacier [9877-48]

\section{SAR IMAGING FOR NISAR SCIENCE II: CRYOSPHERE}

987716 Evaluating suitability of Pol-SAR (TerraSAR-X, Radarsat-2) for automated sea ice classification [9877-50]

987717 Role of Indian remote sensing imaging satellites for the Antarctic monitoring and mapping: a case study around Indian Antarctic research stations [9877-51]

987718 Feature extraction using multi-temporal fully polarimetric SAR data [9877-52]

987719 Ice sheet features identification, glacier velocity estimation, and glacier zones classification using high-resolution optical and SAR data [9877-53]

FOREST MANAGEMENT, WILDLIFE, AND BIOMASS

9877 1 A Forest fire danger index based on modifying Nesterov Index, fuel, and anthropogenic activities using MODIS TERRA, AQUA and TRMM satellite datasets [9877-54]

9877 1B Forest biophysical parameter estimation using space-borne bistatic PollnSAR measurements [9877-55]

\section{WATER RESOURCES MANAGEMENT}

$9877 \mathrm{IF} \quad$ Long-term change analysis of satellite-based evapotranspiration over Indian vegetated surface [9877-59] 
$987711 \quad$ A geomorphic and morphometric analysis of surface ice velocity variation of different valley type glaciers [9877-62]

9877 1K Comparisons of different methods for debris covered glacier classification [9877-64]

POSTER SESSION I

9877 1M Light absorbing impurity deposition over the Himalayan-Karakoram-Hindu Kush-Tibetan cryosphere: a review and satellite-based characterization [9877-17]

987720 Remote sensing for estimating agricultural land use change as the impact of climate change [9877-80]

987721 Urban area mapping from polarimetric SAR data using fuzzy inference system [9877-81]

987726 Effect of polarization orientation angle shift on X-band TDM SAR COSSC product of TerraSAR-X and TanDEM-X [9877-87]

987727 Detection of heat wave using Kalpana-1 VHRR land surface temperature product over India [9877-89]

987729 Semi-empirical modelling for forest above ground biomass estimation using hybrid and fully PolSAR data [9877-91]

9877 2A Analysis of spatio-temporal variations in snow cover over Western Himalaya [9877-92]

\section{POSTER SESSION II}

9877 2B Soil moisture variability across different scales in an Indian watershed for satellite soil moisture product validation [9877-3]

$98772 \mathrm{C}$ Sub-surface paleochannel detection in DeGrussa area, Western Australia, using thermal infrared remote sensing [9877-93]

$98772 \mathrm{E}$ Generation of a precise DEM by interactive synthesis of multi-temporal elevation datasets: a case study of Schirmacher Oasis, East Antarctica [9877-95]

$98772 \mathrm{G}$ Satellite information of sea ice for model validation [9877-97]

$98772 \mathrm{H} \quad$ Inter-comparison of GRACE data over India [9877-98]

9877 2K Damage extraction of buildings in the 2015 Gorkha, Nepal earthquake from high-resolution SAR data [9877-101]

$9877 \mathrm{~L} \quad$ Object-oriented feature extraction approach for mapping supraglacial debris in Schirmacher Oasis using very high-resolution satellite data [9877-102] 
9877 2M Application of high-resolution multispectral data for mapping blue ice areas in the Antarctic environment [9877-103]

$98772 \mathrm{~N} \quad$ Geospatial mapping of vegetation in the Antarctic environment using very high-resolution WorldView-2 imagery [9877-104]

9877 2X Impact of rapid urbanization on the microclimate of Indian cities: a case study for the city of Bhubaneswar [9877-114]

$98772 Y$ Predicting future changes in climate and its impact on change in land use: a case study of Cauvery Basin [9877-116]

$98772 Z$ Mitigation of Faraday rotation in ALOS-2/PALSAR-2 full polarimetric SAR imageries [9877-117]

987730 Analysis of seismo-ionospheric perturbations using modified covariance algorithm [9877-118] 


\section{Authors}

Numbers in the index correspond to the last two digits of the six-digit citation identifier (CID) article numbering system used in Proceedings of SPIE. The first four digits reflect the volume number. Base 36 numbering is employed for the last two digits and indicates the order of articles within the volume. Numbers start with 00, 01, 02, 03, 04, 05, 06, 07, 08, 09, OA, OB...0Z, followed by 10-1Z, 20-2Z, etc.

\author{
A. D., Udhayaraj, 2N \\ Aggarwal, S. P., 19 \\ Agrawal, Neeraj, 08 \\ Agrawal, Shefali, 07 \\ Agrawal, Shefali, 09 \\ Ahluwalia, Asmeet, 21 \\ Ahluwalia, R. S., 11 \\ Arora, Manoj K., 11 \\ Bahri, Rendy, 2K \\ Banerjee, Chandan, $2 \mathrm{H}$ \\ Baranoski, Gladimir V. G., ON \\ Bhan, S. C., OV \\ Bharti, Rajiv R., OK \\ Bhattacharya, Avik, 21 \\ Bhattacharya, Bimal K., OX, IF \\ Chauhan, P., 11 \\ Chawla, Saket, 17 \\ Chen, Tenn F., ON \\ Chouksey, Arpit, 19 \\ Chudasama, Bijal, 2C \\ Darji, Nikunj P., 27 \\ Dash, J., 2X \\ Dewi, W. S., 20 \\ Dinh, Ho Tong Minh, 09 \\ Dixit, Ankur, 19 \\ Gaddam, Vinay Kumar, 2A \\ Garg, P. K., 11, 1K \\ Garg, R. D., 05 \\ Gautam, Ritesh, 1M \\ González-Álvarez, Ignacio, 2C \\ Goyal, Pramila, $2 Y$ \\ Gupta, Asmita, 26 \\ Gupta, Ravi P., 11 \\ Gupta, Shweta, 1F \\ Jadhav, Ajay, 2L \\ Jana, Raghavendra B., 2B \\ Jawak, Shridhar D., 2E, 2L, 2M, 2N \\ Joshi, Sushil Kumar, 07, 09, 29 \\ K. S., Ramesh, 30 \\ K. V., Suresh Babu, 1A \\ Khati, Unmesh, 1B \\ Kiran, K. Uday, 30 \\ Kodamana, Rithwik, 1M \\ Komariah, , 20 \\ Krishna, Akhouri Pramod, IF \\ Kumar, A. Senthil , 19 \\ Kumar, Anant, OU \\ Kumar, D. Nagesh, $2 \mathrm{H}$ \\ Kumar, Sanjay, OU
}

Kumar, Shashi, 05, 07, 08, 09, 18, 26, 29

Kushwaha, S. P. S., 05

Lakshminarayana, S., 30

Lehner, Susanne, 16

Lekshmi, K., 2X

Liu, Wen, 2K

Luis, Alvarinho J., 2E, 2L, 2M, 2N

M. N. S., Ramya, 18

Mahapatra, Debasis K., 2G

Maity, Saroj, OX

Manickam, Surendar, 21

Mehra, Raghav, 17

Meloth, Thamban, 2A

Misra, Arundhati, OX

Mitra, A. K., OV

Mitra, Ashis K., 2G

Mohanty, Binayak P., 2B

Mohanty, Shradha, 1B, 2Z

Momin, Imranali M., 2G

Motohka, Takeshi, $\mathrm{OZ}$

Mujiyo, , 20

Nagai, Hiroto, $\mathrm{OZ}$

Natsuaki, Ryo, $0 Z$

Ohki, Masato, $\mathrm{OZ}$

Oza, Sandip R., 17

P. P., Saheed, 2G

P., Jayaprasad, 17

P., Ramachandra Prasad, IA

P., Thanabalan, OY

Panda, Rabindra K., 2B

Pandey, Dharmendra Kr., OX

Pandey, Uttara, 26

Pandya, Mehul R., 27

Parihar, Shaliesh, OV

Patel, Lavkush K., 2A

Pathak, Vishal N., 27

Porwal, Alok, 21, 2C

Poyil, Rohith P., $2 Y$

Pramudya, Y., 20

R., Revathi, 30

R., Vidhya, OY

Rajagopal, E. N., 2G

Rajak, D. Ram, 17

Rao, Yalamanchili S., 15

Ressel, Rudolf, 16

Roberts, G. J., $2 X$

Romanov, Peter, 12

Roy, Arijit, $1 \mathrm{~A}$

Rozaki, Z., 20 
S., Dhanalakshmi, $2 Y$

S., Koteswara Rao, 30

Saini, Varinder, 11, 1K

Sasagawa, Tadashi, 2K

Shah, Dhiraj, 27

Sharma, A. K., OV

Sharma, Parmanand, 2A

Shukla, A., 11, 1K

Singh, Ajit, 2A

Singh, Gulab, 1B, 2 Z

Singh, Gurjeet, 2B

Singh, N., 11

Singha, Suman, 16

Sinha, Rishitosh K., OK

Sivanpillai, Ramesh, OP

Sukoco, T. A., 20

Sumani, , 20

Suzuki, Shinichi, OZ

Swain, D., $2 X$

Thakur, Praveen K., 19

Thakur, Sanchari, 2C

Tiwari, R. K., 11, $1 \mathrm{~K}$

Tolpekin, Valentyn A., 08, 29

Tomar, Kiledar Singh, 29

Tripathy, S., $2 X$

Trivedi, Himanshu J., 27

Van Leeuwen, Spencer, ON

Varugu, Bhuvan K., 15

Verma, Arpita, OU

Vijayan, Sivaprahasam, OK

Vinoj, V., $2 \mathrm{X}$

Watanabe, Manabu, $\mathrm{OZ}$

Yamazaki, Fumio, 2K 


\title{
Symposium Committees
}

\author{
Symposium Chairs
}

Upendra Singh, NASA Langley Research Center (United States)

Vinay Dadhwal, Indian Space Research Organisation (India)

KJ Ramesh, Ministry of Earth Sciences (India)

Symposium Co-chairs

Toshio Iguchi, National Institute of Information and

Communications Technology (Japan)

Jiancheng Shi, Institute of Remote Sensing and Digital Earth

(China)

Honorary Symposium Chairs

A. S. Kiran Kumar, Indian Space Research Organisation (India)

Charles F. Bolden, National Aeronautics and Space Administration (United States)

Jean-Yves Le Gall, Centre National d'Études Spatiales (France)

Naoki Okumura, Japanese Aerospace Exploration Agency

(Japan)

Dazhe Xu, China National Space Administration (China)

Madhavan N. Rajeevan, Ministry of Earth Sciences (India)

Guanhua Xu, Ministry of Science and Technology (China)

Alain Ratier, EUMETSAT (Germany)

Symposium Technical Program Chairs

George J. Komar, National Aeronautics and Space

Administration (United States)

Kohei Mizutani, National Institute of Information and

Communications Technology (Japan)

Tapan Misra, Indian Space Research Organisation (India)

S.S.C. Shenoi, Ministry of Earth Sciences (India)

Xiaohan Liao, China National Remote Sensing Center (China)

Symposium International Organizing Committee

Michael H. Freilich, Chair, National Aeronautics and Space Administration (United States)

Jack A. Kaye, National Aeronautics and Space Administration (United States)

Clayton P. Turner, NASA Langley Research Center (United States) 
David F. Young, NASA Langley Research Center (United States)

Y. V. N. Krishnamurthy, Indian Space Research Organisation (India)

M. Annadurai, Indian Space Research Organisation (India)

Saroj K. Jha, National Hydrographic Centre (India)

E. N. Rajagopal, National Centre for Medium Range Weather Forecasting (India)

M. Ravichandran, National Centre for Antarctic and Ocean Research (India)

Teruyuki Nakajima, Japan Aerospace Exploration Agency (Japan)

Toshiyoshi Kimura, Japan Aerospace Exploration Agency (Japan)

Akimasa Sumi, National Institute for Environmental Studies (Japan)

Haruhisa Shimoda, Tokai University (Japan)

Peng Gong, Tsinghua University (China)

Shunling Liang, Beijing Normal University (China)

Local Organizing Committee

Shibendu S. Ray, Mahalanobis National Crop Forecast Centre (India)

Mahendra Bhutiyani, Defence Terrain Research Laboratory (India)

Vivek Singh, Indian Space Research Organisation (India)

Shiv Prasad Aggarwal, Indian Space Research Organisation (India)

Sameer Saran, Indian Space Research Organisation (India)

Jagvir Singh, Ministry of Earth Sciences (India)

Rishi Kumar, Ministry of Earth Sciences (India)

Rabi N. Sahoo, Indian Agricultural Research Institute (India)

Jai K. Garg, Guru Gobind Singh Indraprastha University (India)

Pawan Kumar Joshi, Jawaharlal Nehru University (India)

Madan M. Kimothi, Mahalanobis National Crop Forecast Centre (India) 


\title{
Conference Committee
}

\author{
Conference Chairs
}

Reza Khanbilvardi, The City University of New York (United States)

Ashwagosh Ganju, Defence Research and Development

Organisation (India)

A. S. Rajawat, Space Applications Center (India)

Jing M. Chen, University of Toronto (Canada)

Conference Co-chairs

Shunlin Liang, University of Maryland, College Park (United States)

Koji Kajiwara, Chiba University (Japan)

Peng Gong, Tsinghua University (China)

M. Rajeevan, Indian Institute of Tropical Meteorology (India)

Conference Program Committee

Ghassem Asrar, U.S. Department of Energy (United States)

Bimal K. Bhattacharya, Space Applications Center (India)

Dara Entekhabi, Massachusetts Institute of Technology (United States)

Mitchell Goldberg, NOAA/JPSS (United States)

Venkat Lakshmi, University of South Carolina (United States)

Zhaoliang Li, Institute of Geographic Sciences and Natural Resources Research (China)

Kyle C. McDonald, City University of New York (United States) and Jet Propulsion Laboratory (United States)

Thamban Meloth, National Center for Antarctic \& Ocean Research (India)

Ashim Kumar Mitra, India Meteorological Department (India)

Peter Romanov, Center for Satellite Applications and Research (United States)

Kamal Vatta, Centers for International Projects Trust (India)

Session Chairs

Opening Ceremony and Plenary Session

Upendra N. Singh, NASA Langley Research Center (United States)

1 Application of New Satellites for Land Processes

Dara Entekhabi, Massachusetts Institute of Technology (United States) 
2 SAR Imaging for NISAR Science I: Forest Structure and Vegetation Kyle C. McDonald, Jet Propulsion Laboratory (United States)

3 Special Session on Space Technology for Climate and Disaster Risk Management in Asia-Pacific

Anil K. Gupta, Nanyang Technological University (Singapore)

4 Global Change and Carbon Cycle

Jing Ming Chen, University of Toronto (Canada)

5 Land Degradation and Desertification

Reza Khanbilvardi, The City University of New York (United States)

6 Agriculture and Crop Production

Jing M. Chen, University of Toronto (Canada)

7 Remote Sensing of Soil Moisture I

Ashim K. Mitra, Ministry of Earth Sciences (India)

8 Remote Sensing of Soil Moisture II

Venkat Lakshmi, University of South Carolina (United States)

9 Application of Satellites on Land Processes

Dara Entekhabi, Massachusetts Institute of Technology (United States)

10 Cryosphere Remote Sensing

Peter Romanov, Center for Satellite Applications and Research (United States)

11 SAR Imaging for NISAR Science II: Cryosphere

Ashwagosh Ganju, Defence Research and Development

Organisation (India)

12 Forest Management, Wildlife, and Biomass

Jing M. Chen, University of Toronto (Canada)

13 Water Resources Management

Reza Khanbilvardi, The City University of New York (United States)

14 Ice and Snow Hydrology

A. S. Rajawat, Space Applications Center (India) 